\title{
Guest Editorial: "Undergraduate Research and the Pursuit of a Meaningful Career"
}

\section{Ian F. McNeely, Associate Dean for Undergraduate Education, College of Arts and Sciences}

What can you do with a philosophy degree? That question-or some version of it-is one I hear a lot, from parents, from students, from politicians, and from concerned laypeople. It's hardly a new question. But it is one that's being asked with increasing urgency the more expensive college becomes. As tuition rises to offset declining state funding, students and parents want to know what they get for going thousands of dollars into debt. There's an urge to play it safe: to major in a marketable field, like business, or economics, or journalism. But now more than ever, it's critical to make the case that any liberal arts degree, whether it be in philosophy or any of the dozens of other disciplines we offer at Oregon, can and does lead to a rewarding and well-paying career. What's the key to clinching this argument? Arguably, it's undergraduate research.

Every discipline in the university imparts critical thinking skills, but research is what puts those skills to the test. Research is hard work; it's where passion finds application; it's the reason we call the disciplines "disciplines." It trains us to ask new questions, to develop new methods of understanding, to synthesize what we discover with what we already know, and to communicate our findings to others-for the benefit of our colleagues and of the wider world. These skills, moreover, are transferable: once developed in one area of focus, a college major, they serve us well throughout our lives, including the several careers that today's college graduates are likely to have by the time they retire.

Employers emphatically agree. When asked what educational practices they feel will better prepare college graduates for success in the workplace, they rank undergraduate research at the very top. ${ }^{\text {S Some }} 83 \%$ want students to "develop research questions in their field and evidencebased analyses." Nearly as many-79\%-want students to "complete a project prior to graduation that demonstrates their acquired knowledge and skills." Collaborative research and team-based projects win particular favor among today's job creators.

I would never want to suggest that the sole purpose of a bachelor's degree is to get a job. But part of the meaning of life is the ability to do work that is satisfying and challenging. Fortunately, employers count among our staunchest allies in defending the liberal arts in general, and undergraduate research in particular, as a path to that goal. More research, they tell us, prepares more adaptable thinkers. Now it's up to us to make such opportunities available to even more of our students here at Oregon.

${ }^{1}$ Hart Research Associates, "It Takes More Than a Major: Employer Priorities for College Learning and Student Success" (April 10, 2013), p. 10. Available at https://www.aacu.org/sites/default/files/files/LEAP/2013_EmployerSurvey.pdf 